\title{
EFFECT OF SOIL TEST BASED FERTILIZER PACKAGE FOR YIELD AND ECONOMIC RETURN OF LENTIL + MUSTARD MIXED CROPPING SYSTEM IN CHARLAND OF PABNA
}

\author{
M. Maniruzzaman*, M. Robiul Alam², M.S. Islam³ , M.Z. Islam¹, M.S.H. Molla ${ }^{4}$ and M.A. \\ Islam $^{5}$
}

${ }^{1}$ Scientific Officer, ${ }^{2}$ Senior Scientific Officer, ${ }^{3}$ Principal Scientific Officer, OFRD, BARI, Pabna, ${ }^{4}$ Senior Scientific Officer, OFRD, BARI, Rangpur, and ${ }^{5}$ Scientific Officer, OFRD, BARI, Shampur, Rajshahi Corresponding E-mail: maniruzzaman.bari@yahoo.com

(Received: 21 December 2017, Accepted: 16 September 2019)

Keywords: Mixed cropping, char land, lentil, mustard, lentil equivalent yield, economic return

\begin{abstract}
The experiment was conducted at char Sadipur the char land of Pabna during the Rabi season of 2013-14 and 2014-15 to determine appropriate fertilizer dose for enhancing production and economic return from Lentil+ Mustard mixed cropping system. The experiment was laid out in a randomized complete block design with 3 dispersed replications. Eight soil test based fertilizer packages viz., $\mathrm{T}_{1}$ : $\mathrm{N}_{20} \mathrm{P}_{24} \mathrm{~K}_{20} \mathrm{~S}_{18} \mathrm{Zn}_{2} \mathrm{~B}_{1.5}, \mathrm{~T}_{2}$ : $\mathrm{N}_{25} \mathrm{P}_{24} \mathrm{~K}_{20} \mathrm{~S}_{18} Z_{\mathrm{n}_{2}} \mathrm{~B}_{1.5}, \mathrm{~T}_{3}: \mathrm{N}_{25} \mathrm{P}_{30} \mathrm{~K}_{20} \mathrm{~S}_{18} \mathrm{Zn}_{2} \mathrm{~B}_{1.5}, \mathrm{~T}_{4}: \mathrm{N}_{25} \mathrm{P}_{24} \mathrm{~K}_{25} \mathrm{~S}_{18}$ $Z_{n_{2}} B_{1.5}, T_{5}: N_{20} P_{30} K_{25} S_{18} Z_{2} B_{1.5}, T_{6}: N_{25} P_{30} K_{25} S_{18} Z_{2} B_{1.5}, T_{7}: N_{15}$ $\mathrm{P}_{18} \mathrm{~K}_{15} \mathrm{~S}_{14} \mathrm{Zn}_{1.5} \mathrm{~B}_{1} \mathrm{~kg}$ ha ${ }^{-1} \mathrm{~kg}$ ha ${ }^{-1}$ and $\mathrm{T}_{8}$ : native nutrient (control) were tested for lentil + mustard mixed cropping system. Soil test based $\mathrm{N}_{25} \mathrm{P}_{30}$ $\mathrm{K}_{25} \mathrm{~S}_{18} \mathrm{Zn}_{2} \mathrm{~B}_{1.5}\left(\mathrm{~T}_{6}\right)$ showed better performance on crop growth and yield of lentil and mustard in lentil+ mustard mixed cropping system in both the year. The highest lentil yield $0.70 \mathrm{t} \mathrm{ha}^{-1}$ in 2013-14 and $0.95 \mathrm{t}$ ha 1 in 2014-15 was obtained from soil test based $N_{25} P_{30} K_{25} S_{18} Z_{2} B_{1.5}$ $\left(\mathrm{T}_{6}\right)$. Similarly, maximum lentil equivalent yield (1233 Kg ha ${ }^{-1}$ in 2013-14 and $1280 \mathrm{Kg} \mathrm{ha}^{-1}$ in 2014-15) was also obtained from the same treatment. The maximum gross margin (Tk. 31639 ha $^{-1}$ in 2013-14 and Tk. 32480 ha $^{-1}$ in 2014-15) was recorded from soil test based $\mathrm{N}_{25} \mathrm{P}_{30}$ $\mathrm{K}_{25} \mathrm{~S}_{18} \mathrm{Zn}_{2} \mathrm{~B}_{1.5}$. So, application of soil test based fertilizer increases lentil and mustard yield as mixed crop as well as income of the farmers.
\end{abstract}

\section{Introduction}

In Bangladesh the lands of char area are not suitable for all crops and all seasons. In Pabna, there is a vast area of char land under AEZ-11. Nutrient status of char land is poor due to coarse textured soils, low water holding capacity, low nutrient content, river bank erosion and flooding. Farmers of char land in Pabna generally grow lentil and mustard as mixed crop where they use local variety with no or limited fertilizers. For this reason, the yield of lentil and mustard in this region is much below than that of potential yield level. Balanced fertilization can play a major role to enhance the present yield level. Experimental evidences reveal that the crop is highly responsive to different fertilizers and its yield can be increased remarkably through the judicious fertilization (BARI, 1988; Mohamed,1984; Roy and Singh, 1986; Kazi et al., 2002). Fertilizer recommendation solely based on crop response data often fails to show economic viability. In this context, Perrin et al. (1979) reported that response of yield should be supported by economic evaluation for judicious fertilizer recommendation. Since the application of optimum dose of fertilizer is important for increasing the yield of lentil and mustard mixed cropping system, 
but very limited information in this regard is available in Bangladesh, the present study was undertaken to determine the optimum fertilizer dose of lentil and mustard mixed crop in char land.

\section{Materials and Methods}

The experiment was conducted at char land of Char Sadipur areas of Pabna during Rabi season of 2014-15 to 2015-16. The experimental site was in Gopalpur soil series belonging to the High Ganges River Floodplain Soils (AEZ11). Before starting the experiment, initial composite soil samples $(0-15 \mathrm{~cm}$ depth) were collected from the experimental plots and were analyzed. The analytical result indicated that soil was sandy loam with very low organic matter content $(0.82 \%)$ and slightly alkaline in nature. $\mathrm{N}$ content of soil was very low and $\mathrm{P}, \mathrm{S}$ and $\mathrm{Zn}$ content of the soil were low. $\mathrm{K}$ content of the soil was medium (Table 1).

Table 1. Nutrient status of the initial soil sample $(0-15 \mathrm{~cm}$ depth) of experimental plots at Char Sadipur, Pabna

\begin{tabular}{lcc}
\hline \multicolumn{1}{c}{ Soil properties } & Values & Interpretation \\
\hline Soil pH & 8.1 & Slightly alkaline \\
Organic matter content (\%) & 0.82 & Very low \\
Total N (\%) & 0.05 & Very low \\
Available P ( $\mu \mathrm{g} / \mathrm{g}$ soil) & 11.3 & Low \\
Available S ( $\mu \mathrm{g} / \mathrm{g}$ soil) & 9.2 & Low \\
Available $\mathrm{Zn}(\mu \mathrm{g} / \mathrm{g}$ soil) & 0.57 & Low \\
Exchangeable K (meq\%) & 0.17 & Medium \\
\hline
\end{tabular}

Eight treatments consisted of $\mathrm{T}_{1}: \mathrm{N}_{20} \mathrm{P}_{24} \mathrm{~K}_{20} \mathrm{~S}_{18} \mathrm{Zn}_{2} \mathrm{~B}_{1.5} \quad$ (STB), $\mathrm{T}_{2}: \mathrm{N}_{25} \mathrm{P}_{24} \mathrm{~K}_{20}$ $\mathrm{S}_{18} \mathrm{Zn}_{2} \mathrm{~B}_{1.5}, \mathrm{~T}_{3}: \mathrm{N}_{25} \mathrm{P}_{30} \mathrm{~K}_{20} \mathrm{~S}_{18} \mathrm{Zn}_{2} \mathrm{~B}_{1.5}, \mathrm{~T}_{4}: \mathrm{N}_{25} \mathrm{P}_{24} \mathrm{~K}_{25} \mathrm{~S}_{18} \mathrm{Zn}_{2} \mathrm{~B}_{1.5}, \mathrm{~T}_{5}: \mathrm{N}_{20} \mathrm{P}_{30}$ $\mathrm{K}_{25} \mathrm{~S}_{18} \mathrm{Zn}_{2} \mathrm{~B}_{1.5}, \mathrm{~T}_{6}: \mathrm{N}_{25} \mathrm{P}_{30} \mathrm{~K}_{25} \mathrm{~S}_{18} \mathrm{Zn}_{2} \mathrm{~B}_{1.5}, \mathrm{~T}_{7}: \mathrm{N}_{15} \mathrm{P}_{18} \mathrm{~K}_{15} \mathrm{~S}_{14} \mathrm{Zn}_{1.5} \mathrm{~B}_{1} \mathrm{~kg}$ ha ${ }^{-1}$ and $\mathrm{T}_{8}$ : native nutrient (control that is without fertilizer).

The experiment was laid out in randomized complete block (RCB) design with three replications. The unit plot size was $5 \mathrm{~m} \times 4 \mathrm{~m}$. The land was prepared by power tiller and laddering. After completion of land preparation, the entire amount of all fertilizers was applied as per treatment specification. The seeds of lentil and mustard were broadcasted in each plot on 10 November in 2013-14 and 15 November in 2014-15 maintaining the same ratio of $80: 20$ for lentil + mustard mixed crop in both the season. Two times weeding were done at vegetative stage for better growth of the crops. Rovral 50 WP @ $2.5 \mathrm{~g} \mathrm{~L}^{-1}$ was applied 3 times at 7-10 days interval from flowering until pod formation to control stem phylum disease of lentil. Other intercultural operations were done when required. Mustard was harvested on 5 February in 2013-14 and 10 February in 2014-15 while lentil was harvested on 23 February in 2013-4 and 27 Februaryin 2014-15 cropping season. Other intercultural operations were done when required. Necessary data on days to flowering, days to maturity, yield and yield contributing characters were collected and analyzed through statistical analytical package with MSTAT $\mathrm{C}$ software. The productivity of mixed cropping system was estimated by calculating their lentil equivalent yield (LEY) using formula given by Ahlawat and Sharma(1993), where

$$
\text { LER }=\frac{\text { Yield of mustard }(\mathrm{t} / \mathrm{ha}) X \text { Price of mustard grain }(T k . / t)}{\text { Price of lentil grain }(T k . / t)}
$$

Cost and return analysis of different treatments were done for gross margin. 


\section{Results and Discussion}

Plant height and yield contributing characters of lentil in lentil + mustard mixed cropping system have been presented in Table 2a. Significant variation in Plant height, No. of pods

plant $^{-1}$, No. of seed pod $^{-1}$, and 1000-seed weight were observed-in different treatments. The highest plant height $(27 \mathrm{~cm}$ and $30.7 \mathrm{~cm})$ was measured from $\mathrm{N}_{25}$ $\mathrm{P}_{30} \mathrm{~K}_{25} \mathrm{~S}_{18} \mathrm{Zn}_{2} \mathrm{~B}_{1.5}\left(\mathrm{~T}_{6}\right)$ treatment, which was significant irrespective of years and the lowest plant height $(20.1 \mathrm{~cm}$ and $21.87 \mathrm{~cm})$ was measured in $\mathrm{T}_{8}$ (control). In case of number of seeds pod ${ }^{-1}$ there was no significant difference among the treatments except $T_{4}$ and control in 2013-14 and only control in 2014-15 cropping season. Higher 1000-seed weight was observed from $T_{6}, T_{5}, T_{4}$ and $T_{2}$ but $\mathrm{T}_{5}$ was not higher in 2013-14 and the lowest 1000-seed weight $(24.83 \mathrm{~g}$ and 18.07g)-from control $\left(\mathrm{T}_{8}\right)$. Performance of $\mathrm{T}_{3}$ regarding yield contributing parameters is poor though $\mathrm{N}$ and $\mathrm{P}$ level was used in higher dose compare to other treatments might be due to lower dose of $\mathrm{K}$. Char land soil is light textured soil and contain very low N, P, K, S, Zn and B. For that application of higher dose of $\mathrm{N}, \mathrm{P}$ and $\mathrm{K}$ show higher growth and yield contributing characters. This results are supported by Anonymous (2009) as it reported that application of N, P, B and Rhizobium inoculum significantly enhanced the positive growth and yield parameters of lentil.

Table 2a. Plant Height and Yield contributing parameters of lentil in lentil + mustard mixed cropping system at Char Sadipur, Pabna during the rabi season of 2013-14 and 2014-15

\begin{tabular}{|c|c|c|c|c|c|c|c|c|}
\hline \multirow{2}{*}{ Treatment } & \multicolumn{2}{|c|}{ Plant height $(\mathrm{cm})$} & \multicolumn{2}{|c|}{ No. of pods plant ${ }^{-1}$} & \multicolumn{2}{|c|}{ No. of seed pod $^{-1}$} & \multicolumn{2}{|c|}{ 1000- seed weight (g) } \\
\hline & 2013-14 & $2014-15$ & 2013-14 & 2014-15 & 2013-14 & $2014-15$ & 2013-14 & $2014-15$ \\
\hline $\mathrm{T}_{1}$ & 24.43 de & $23.17 \mathrm{c}$ & $26.90 \mathrm{bc}$ & $30.00 \mathrm{bcd}$ & $1.83 \mathrm{ab}$ & 1.70abc & $19.40 \mathrm{~b}$ & $\begin{array}{c}25.17 \\
\text { bc }\end{array}$ \\
\hline $\mathrm{T}_{2}$ & $26.40 \mathrm{bcd}$ & $24.57 b c$ & $27.00 \mathrm{bc}$ & $\begin{array}{c}36.33 \\
a b\end{array}$ & $1.83 \mathrm{ab}$ & 1.70abc & 20.13 a & $\begin{array}{c}25.67 \\
a b\end{array}$ \\
\hline $\mathrm{T}_{3}$ & $27.73 \mathrm{abc}$ & $24.47 \mathrm{bc}$ & $31.33 \mathrm{ab}$ & $34.60 \mathrm{abc}$ & $1.83 \mathrm{ab}$ & 1.70abc & $19.63 \mathrm{~b}$ & $\begin{array}{l}25.00 \\
\text { bc }\end{array}$ \\
\hline $\mathrm{T}_{4}$ & $28.90 \mathrm{ab}$ & $\begin{array}{c}25.07 \\
\mathrm{~b}\end{array}$ & $31.00 \mathrm{ab}$ & $29.57 \mathrm{~cd}$ & $1.90 \mathrm{a}$ & $1.63 \mathrm{bc}$ & $\begin{array}{c}19.93 \\
a b\end{array}$ & $\begin{array}{l}25.67 \\
\mathrm{ab}\end{array}$ \\
\hline $\mathrm{T}_{5}$ & $25.43 \mathrm{~cd}$ & $24.03 \mathrm{bc}$ & $32.63 \mathrm{ab}$ & $30.40 \mathrm{bcd}$ & $1.93 \mathrm{a}$ & 1.70abc & $20.73 \mathrm{a}$ & $\begin{array}{l}25.50 \\
b c\end{array}$ \\
\hline $\mathrm{T}_{6}$ & 30.70 a & $\begin{array}{c}27.00 \\
a\end{array}$ & $38.33 \mathrm{a}$ & $38.40 \mathrm{a}$ & $1.90 \mathrm{a}$ & $1.76 \mathrm{a}$ & $20.80 \mathrm{a}$ & $26.33 \mathrm{a}$ \\
\hline $\mathrm{T}_{7}$ & $23.80 \mathrm{de}$ & $23.47 b c$ & $23.47 b c$ & $\begin{array}{c}26.73 \\
\text { de }\end{array}$ & $1.80 \mathrm{ab}$ & $1.73 \mathrm{ab}$ & $\begin{array}{c}18.63 \\
\text { bc }\end{array}$ & $\begin{array}{c}25.33 \\
\text { bc }\end{array}$ \\
\hline $\mathrm{T}_{8}$ & 21.87 e & $\begin{array}{c}20.10 \\
d\end{array}$ & $20.30 \mathrm{c}$ & $21.63 e$ & $1.70 \mathrm{~b}$ & $1.60 \mathrm{c}$ & $18.07 \mathrm{c}$ & $24.83 \mathrm{c}$ \\
\hline $\mathrm{CV}(\%)$ & 6.51 & 4.03 & 18.34 & 12.47 & 4.89 & 4.30 & 3.50 & 1.80 \\
\hline
\end{tabular}

$\mathrm{T}_{1}: \mathrm{N}_{20} \mathrm{P}_{24} \mathrm{~K}_{20} \mathrm{~S}_{18} \mathrm{Zn}_{2} \mathrm{~B}_{1.5}$ (STB), $\mathrm{T}_{2}: \mathrm{N}_{25} \mathrm{P}_{24} \mathrm{~K}_{20} \mathrm{~S}_{18} \mathrm{Zn}_{2} \mathrm{~B}_{1.5}, \mathrm{~T}_{3}: \mathrm{N}_{25} \mathrm{P}_{30} \mathrm{~K}_{20} \mathrm{~S}_{18} \mathrm{Zn}_{2} \mathrm{~B}_{1.5}, \mathrm{~T}_{4}$ : $\mathrm{N}_{25} \mathrm{P}_{24} \mathrm{~K}_{25} \mathrm{~S}_{18} \mathrm{Zn}_{2} \mathrm{~B}_{1.5}, \mathrm{~T}_{5}: \mathrm{N}_{20} \mathrm{P}_{30} \mathrm{~K}_{25} \mathrm{~S}_{18} \mathrm{Zn}_{2} \mathrm{~B}_{1.5}, \mathrm{~T}_{6}: \mathrm{N}_{25} \mathrm{P}_{30} \mathrm{~K}_{25} \mathrm{~S}_{18} \mathrm{Zn}_{2} \mathrm{~B}_{1.5}, \mathrm{~T}_{7}: \mathrm{N}_{15} \mathrm{P}_{18} \mathrm{~K}_{15}$ $\mathrm{S}_{14} \mathrm{Zn}_{1 .} \mathrm{B}_{1} \mathrm{~kg}$ ha-1 and $\mathrm{T}_{8}$ : native nutrient (control)

Yield of lentil and mustard in mixed cropping system have been presented in Table 2b. In 2014-15 maximum stover yield of lentil $\left(0.75 \mathrm{t} \mathrm{ha}^{-1}\right.$ and $0.79 \mathrm{t}$ ha $^{-1}$ ) was found from $\mathrm{N}_{25} \mathrm{P}_{30} \mathrm{~K}_{25} \mathrm{~S}_{18} \mathrm{Zn}_{2} \mathrm{~B}_{1.5}\left(\mathrm{~T}_{6}\right)$ treatment, which was statistically similar to $T_{5}$ and $T_{3}$ while minimum stover yield $0.31 \mathrm{t}$ ha ${ }^{-1}$ from control $\left(T_{8}\right)$. In 2013-14, the maximum stover yield was observed from the treatment $\mathrm{N}_{25} \mathrm{P}_{30}$ $\mathrm{K}_{25} \mathrm{~S}_{18} \mathrm{Zn}_{2} \mathrm{~B}_{1.5}\left(\mathrm{~T}_{6}\right)$ followed by $\mathrm{T}_{5}, \mathrm{~T}_{4}$ and $\mathrm{T}_{3}$ and the minimum stover yield was found from the control treatment which was statistically similar to the treatment $\mathrm{T}_{7}$ (Table 2b). However, the highest seed yield $0.95 \mathrm{t}$ ha ${ }^{-1}$ was attained from $\mathrm{N}_{25}$ 
$\mathrm{P}_{30} \mathrm{~K}_{25} \mathrm{~S}_{18} \quad \mathrm{Zn}_{2} \mathrm{~B}_{1.5}\left(\mathrm{~T}_{6}\right)$ which was significantly higher than other treatments in 2014-15 cropping season but in 2013-14 cropping season, the highest seed yield $\left(0.70 \mathrm{t} \mathrm{ha}^{-1}\right)$ was found from the treatment $\mathrm{T}_{6}$ which was statistically similar with $\mathrm{T}_{5}, \mathrm{~T}_{4}$ and $\mathrm{T}_{3}$. On the contrary, control $\left(\mathrm{T}_{8}\right)$ treatment provided the lowest lentil yield $\left(0.41 \mathrm{t} \mathrm{ha}^{-1}\right.$ and $\left.0.21 \mathrm{t} \mathrm{ha}^{-1}\right)$. The cumulative contribution of potential yield traits might be the reason for higher seed yield from $N_{25} P_{30} K_{25} S_{18} Z_{2}$ $\mathrm{B}_{1.5}\left(\mathrm{~T}_{6}\right)$. In contrast, poor crop growth and yield traits resulted in the lowest seed yield in control $\left(\mathrm{T}_{8}\right)$. Maximum lentil yield increased (132\% and 233\%) over control was obtained from $\mathrm{N}_{25} \mathrm{P}_{38} \mathrm{~K}_{31} \mathrm{~S}_{18} \mathrm{Zn}_{3} \mathrm{~B}_{1.5}\left(\mathrm{~T}_{6}\right)$ in 2014-15 and 2013-14 respectively. The overall results indicate that in char land conditions soils are dominated with sand particles and low organic matter which causes deficiency in nutrient availability in soil and make imbalance in subsequent plant uptake. Therefore, $100 \%$ fertilizer package plus 25\% additional nutrients specially N,P and $\mathrm{K}$ that is fertilizer dose $\mathrm{N}_{25} \mathrm{P}_{30} \quad \mathrm{~K}_{25} \mathrm{~S}_{18} \mathrm{Zn}_{2} \mathrm{~B}_{1.5}$ enhance optimum plant growth and development and higher yield in lentil. Anonymous (2009) reported that balanced application of $\mathrm{N}, \mathrm{P}, \mathrm{K}, \mathrm{S}, \mathrm{Zn}$ and $\mathrm{B}$ significantly increased the yield of lentil over control. The results obtained in this experiment are supported by the findings of Mondal et al. (2010); Bhuiyan et al. (2008) and Singh et al. (2004) found that yield of lentil increases when fertilizer was applied as soil test based.

In case of mustard as mixed crop, similar trend was observed as lentil in both the season. The maximum mustard seed yield $\left(0.38 \mathrm{t} \mathrm{ha}^{-1}\right.$ and $\left.0.66 \mathrm{t} \mathrm{ha}^{-1}\right)$ was recorded from $\mathrm{N}_{25} \mathrm{P}_{30} \quad \mathrm{~K}_{25} \mathrm{~S}_{18} \mathrm{Zn}_{2} \mathrm{~B}_{1.5}\left(\mathrm{~T}_{6}\right)$. The exclusion of fertilizer that is control $\left(\mathrm{T}_{8}\right)$ plot resulted in the lowest seed yield (Table $\left.2 \mathrm{~b}\right)$. The seed yield of lentil is higher in second year than first year while the seed yield of mustard is higher in first year than second year. It might be due to mixed cropping by which two crops sharing their yield that is when one crop performs better then another crop could perform poor. Bhowal et al. (2014) also found that when lentil perform better then mustard's performance was not good enough in mixed cropping system.

Table 2b. Stover yield, seed yield of lentil and mustard in lentil + mustard mixed cropping system at Char Sadipur, Pabna during the Rabi season of 201314 and 2014-15

\begin{tabular}{cccccccccc}
\hline Treatments & $\begin{array}{c}\text { Stover yield of lentil } \\
\left(\mathrm{t} \mathrm{h} \mathrm{A}^{-1}\right)\end{array}$ & \multicolumn{2}{c}{$\begin{array}{c}\text { Seed yield of lentil } \\
\left(\mathrm{t} \text { ha }^{-1}\right)\end{array}$} & $\begin{array}{c}\text { Seed yield of mustard } \\
(\mathrm{t} \mathrm{ha-1})\end{array}$ & $\begin{array}{c}\text { \% Yield increase of } \\
\text { lentil over control }\left(\mathrm{T}_{8}\right)\end{array}$ \\
\cline { 2 - 11 } & $2013-14$ & $2014-15$ & $2013-14$ & $2014-15$ & $2013-14$ & $2014-15$ & $2013-14$ & $2014-15$ \\
\hline $\mathrm{T}_{1}$ & $0.41 \mathrm{c}$ & $0.51 \mathrm{bc}$ & $0.43 \mathrm{~cd}$ & $0.73 \mathrm{~b}$ & $0.25 \mathrm{~d}$ & $0.20 \mathrm{~cd}$ & 105 & 78 \\
$\mathrm{~T}_{2}$ & $0.45 \mathrm{c}$ & $0.55 \mathrm{bc}$ & $0.47 \mathrm{bc}$ & $0.74 \mathrm{~b}$ & $0.28 \mathrm{~d}$ & $0.22 \mathrm{bcd}$ & 124 & 80 \\
$\mathrm{~T}_{3}$ & $0.60 \mathrm{~b}$ & $0.63 \mathrm{ab}$ & $0.56 \mathrm{abc}$ & $0.78 \mathrm{~b}$ & $0.38 \mathrm{c}$ & $0.23 \mathrm{bc}$ & 167 & 90 \\
$\mathrm{~T}_{4}$ & $0.60 \mathrm{~b}$ & $0.61 \mathrm{~b}$ & $0.56 \mathrm{abc}$ & $0.74 \mathrm{~b}$ & $0.51 \mathrm{~b}$ & $0.25 \mathrm{~b}$ & 167 & 80 \\
$\mathrm{~T}_{5}$ & $0.66 \mathrm{~b}$ & $0.65 \mathrm{ab}$ & $0.61 \mathrm{ab}$ & $0.75 \mathrm{~b}$ & $0.46 \mathrm{bc}$ & $0.26 \mathrm{~b}$ & 190 & 83 \\
$\mathrm{~T}_{6}$ & $0.79 \mathrm{a}$ & $0.75 \mathrm{a}$ & $0.70 \mathrm{a}$ & $0.95 \mathrm{a}$ & $0.66 \mathrm{a}$ & $0.38 \mathrm{a}$ & 233 & 132 \\
$\mathrm{~T}_{7}$ & $0.33 \mathrm{~cd}$ & $0.45 \mathrm{~cd}$ & $0.38 \mathrm{~d}$ & $0.60 \mathrm{c}$ & $0.25 \mathrm{~d}$ & $0.19 \mathrm{~d}$ & 81 & 46 \\
$\mathrm{~T}_{8}$ & $0.23 \mathrm{~d}$ & $0.31 \mathrm{~d}$ & $0.21 \mathrm{e}$ & $0.41 \mathrm{~d}$ & $0.06 \mathrm{e}$ & $0.04 \mathrm{e}$ & - & - \\
\hline $\mathrm{CV}(\%)$ & 13.36 & 13.82 & 19.20 & 8.64 & 15.98 & 24.51 & & \\
\hline
\end{tabular}

$\mathrm{T}_{1}: \mathrm{N}_{20} \mathrm{P}_{24} \mathrm{~K}_{20} \mathrm{~S}_{18} \mathrm{Zn}_{2} \mathrm{~B}_{1.5}$ (STB), $\mathrm{T}_{2}: \mathrm{N}_{25} \mathrm{P}_{24} \mathrm{~K}_{20} \mathrm{~S}_{18} \mathrm{Zn}_{2} \mathrm{~B}_{1.5}, \mathrm{~T}_{3}: \mathrm{N}_{25} \mathrm{P}_{30} \mathrm{~K}_{20} \mathrm{~S}_{18} Z_{2} \mathrm{n}_{2} \mathrm{~B}_{1.5}, \mathrm{~T}_{4}$ : $\mathrm{N}_{25} \mathrm{P}_{24} \mathrm{~K}_{25} \mathrm{~S}_{18} \mathrm{Zn}_{2} \mathrm{~B}_{1.5}, \mathrm{~T}_{5}: \mathrm{N}_{20} \mathrm{P}_{30} \mathrm{~K}_{25} \mathrm{~S}_{18} \mathrm{Zn}_{2} \mathrm{~B}_{1.5}, \mathrm{~T}_{6}: \mathrm{N}_{25} \mathrm{P}_{30} \mathrm{~K}_{25} \mathrm{~S}_{18} \mathrm{Zn}_{2} \mathrm{~B}_{1.5}, \mathrm{~T}_{7}: \mathrm{N}_{15} \mathrm{P}_{18} \mathrm{~K}_{15}$ $\mathrm{S}_{14} \mathrm{Zn}_{1.5} \mathrm{~B}_{1} \mathrm{~kg}$ ha ${ }^{-1}$ and $\mathrm{T}_{8}$ : native nutrient (control)

However, maximum lentil equivalent yield (1280 Kg ha-1 and $1233 \mathrm{Kg} \mathrm{ha}^{-1}$ ) was found from $\mathrm{N}_{25} \mathrm{P}_{30} \mathrm{~K}_{25} \mathrm{~S}_{18} \mathrm{Zn}_{2} \mathrm{~B}_{1.5}\left(\mathrm{~T}_{6}\right)$ which is $355 \%$ and $176 \%$ higher over control in 2013-14 and 2014-15 cropping season, respectively while minimum lentil equivalent yield $\left(271 \mathrm{Kg} \mathrm{ha}^{-1}\right.$ and $463 \mathrm{Kg} \mathrm{ha}^{-1}$ ) was found from control $\left(\mathrm{T}_{8}\right)$ 
plot (Table 2c). The results of this experiment indicate that soil health in char land is relatively poor which does not provide proper nutrient backup to the crops. Due to having very low organic matter and plant nutrition, higher rate of fertilizer management results in higher crop yield.

Table 2c. Lentil equivalent yield and \% increase of lentil equivalent yield over control in lentil+ mustard mixed cropping system at Char Sadipur, Pabna during the Rabi season of 2013-14 and 2014-15

\begin{tabular}{lcccc}
\hline \multirow{2}{*}{ Treatments } & \multicolumn{2}{c}{$\begin{array}{c}\text { Lentil equivalent yield } \\
\left(\mathrm{Kg} \mathrm{ha}^{-1}\right)\end{array}$} & \multicolumn{2}{c}{$\begin{array}{c}\text { \% Lentil equivalent yield } \\
\text { increase over control }\left(\mathrm{T}_{8}\right)\end{array}$} \\
\cline { 2 - 5 } & $2013-14$ & $2014-15$ & $2013-14$ & $2014-15$ \\
\hline $\mathrm{T}_{1}: \mathrm{N}_{20} \mathrm{P}_{24} \mathrm{~K}_{20} \mathrm{~S}_{18} \mathrm{Zn}_{2} \mathrm{~B}_{1.5}$ & 641 & 913 & 137 & 97 \\
$\mathrm{~T}_{2}: \mathrm{N}_{25} \mathrm{P}_{24} \mathrm{~K}_{20} \mathrm{~S}_{18} \mathrm{Zn}_{2} \mathrm{~B}_{1.5}$ & 705 & 939 & 160 & 103 \\
$\mathrm{~T}_{3}: \mathrm{N}_{25} \mathrm{P}_{30} \mathrm{~K}_{20} \mathrm{~S}_{18} \mathrm{Zn}_{2} \mathrm{~B}_{1.5}$ & 878 & 994 & 224 & 115 \\
$\mathrm{~T}_{4}: \mathrm{N}_{25} \mathrm{P}_{24} \mathrm{~K}_{25} \mathrm{~S}_{18} \mathrm{Zn}_{2} \mathrm{~B}_{1.5}$ & 971 & 966 & 258 & 109 \\
$\mathrm{~T}_{5}: \mathrm{N}_{20} \mathrm{P}_{30} \mathrm{~K}_{25} \mathrm{~S}_{18} \mathrm{Zn}_{2} \mathrm{~B}_{1.5}$ & 991 & 986 & 266 & 113 \\
$\mathrm{~T}_{6}: \mathrm{N}_{25} \mathrm{P}_{30} \mathrm{~K}_{25} \mathrm{~S}_{18} \mathrm{Zn}_{2} \mathrm{~B}_{1.5}$ & 1233 & 1280 & 355 & 176 \\
$\mathrm{~T}_{7}: \mathrm{N}_{15} \mathrm{P}_{18} \mathrm{~K}_{15} \mathrm{~S}_{14} \mathrm{Zn}_{1.5} \mathrm{~B}_{1}$ & 585 & 771 & 116 & 67 \\
$\mathrm{~T}_{8}:$ Control & 271 & 463 & - & - \\
\hline
\end{tabular}

\section{Economic return from lentil + mustard mixed cropping}

Cost and return analysis demonstrated that gross margin (Tk.32480 ha ${ }^{-1}$ and Tk.31639 ha $\mathrm{ha}^{-1}$ ) was obtained from $\mathrm{N}_{25} \mathrm{P}_{30} \mathrm{~K}_{25} \mathrm{~S}_{18} \mathrm{Zn}_{2} \mathrm{~B}_{1.5}\left(\mathrm{~T}_{6}\right)$ in 2014-15 and 2013-14, respectively followed by $\mathrm{T}_{4}$ and $\mathrm{T}_{5}$ fertilizer management packages (Table 3). Probably higher production and gross return (Tk.83200 ha ${ }^{-1}$ and Tk.80145 ha ${ }^{-1}$ ) from this $\mathrm{T}_{6}$ treatments resulted in higher economic return. Negative gross margin was recorded from control $\left(T_{8}\right)$ in both the year but $T_{1}$, $\mathrm{T}_{2}$ and $\mathrm{T}_{3}$ in 2013-14 cropping season due to poor yield from those treatments and gross return which was lower than the total variable cost.

Table 3. Cost and return analysis of lentil + mustard mixed cropping system influenced by fertilizer packages at Char Sadipur, Pabna during the Rabi season of 2013-14 and 2014-15

\begin{tabular}{lcccccc}
\hline Treatments & \multicolumn{2}{c}{$\begin{array}{c}\text { Gross return } \\
(\text { Tk. ha }\end{array}$} & \multicolumn{2}{c}{$\begin{array}{c}\text { Total variable cost } \\
(\text { Tk. ha }\end{array}$} & \multicolumn{2}{c}{$\begin{array}{c}\text { Gross margin } \\
(\text { Tk. ha }\end{array}$} \\
\cline { 2 - 7 } & $2014-15$ & $2013-14$ & $2014-15$ & $2013-14$ & $2014-15$ & $2013-14$ \\
\hline $\mathrm{T}_{1}$ & 59345 & 41665 & 49670 & 47367 & 9675 & -5682 \\
$\mathrm{~T}_{2}$ & 61035 & 45825 & 49870 & 47565 & 11165 & -1740 \\
$\mathrm{~T}_{3}$ & 64610 & 57070 & 50560 & 48346 & 14050 & 8724 \\
$\mathrm{~T}_{4}$ & 62790 & 63115 & 50030 & 47725 & 12760 & 15390 \\
$\mathrm{~T}_{5}$ & 64090 & 64415 & 50520 & 48308 & 13570 & 16107 \\
$\mathrm{~T}_{6}$ & 83200 & 80145 & 50720 & 48506 & 32480 & 31639 \\
$\mathrm{~T}_{7}$ & 50115 & 38025 & 47620 & 45278 & 2495 & -7253 \\
$\mathrm{~T}_{8}$ & 30095 & 17615 & 41540 & 39010 & -11445 & -21395 \\
\hline
\end{tabular}

$\mathrm{T}_{1}: \mathrm{N}_{20} \mathrm{P}_{24} \mathrm{~K}_{20} \mathrm{~S}_{18} \mathrm{Zn}_{2} \mathrm{~B}_{1.5}$ (STB), $\mathrm{T}_{2}: \mathrm{N}_{25} \mathrm{P}_{24} \mathrm{~K}_{20} \mathrm{~S}_{18} \mathrm{Zn}_{2} \mathrm{~B}_{1.5}, \mathrm{~T}_{3}: \mathrm{N}_{25} \mathrm{P}_{30} \mathrm{~K}_{20} \mathrm{~S}_{18} \mathrm{Zn}_{2} \mathrm{~B}_{1.5}, \mathrm{~T}_{4}:$ $\mathrm{N}_{25} \mathrm{P}_{24} \mathrm{~K}_{25} \mathrm{~S}_{18} \mathrm{Zn}_{2} \mathrm{~B}_{1.5}, \mathrm{~T}_{5}: \mathrm{N}_{20} \mathrm{P}_{30} \mathrm{~K}_{25} \mathrm{~S}_{18} \mathrm{Zn}_{2} \mathrm{~B}_{1.5}, \mathrm{~T}_{6}: \mathrm{N}_{25} \mathrm{P}_{30} \mathrm{~K}_{25} \mathrm{~S}_{18} \mathrm{Zn}_{2} \mathrm{~B}_{1.5}, \mathrm{~T}_{7}: \mathrm{N}_{15} \mathrm{P}_{18} \mathrm{~K}_{15}$ $\mathrm{S}_{14} \mathrm{Zn}_{1.5} \mathrm{~B}_{1} \mathrm{~kg}$ ha ${ }^{-1}$ and $\mathrm{T}_{8}$ : native nutrient (control)

Market Price $\left(\mathrm{Tk} \mathrm{kg}^{-1}\right)$ : Lentil: Grain $=65.00^{1}$, Straw $=5.00$, Mustard: Grain $=45.00^{1}$,

Straw $=1.00$ 


\section{Conclusion}

The findings could be concluded that fertilizer packages exerted significant effect on yield and yield attributes of lentil and mustard in mixed cropping system. Soil test based fertilizer $\mathrm{N}_{25} \mathrm{P}_{30} \mathrm{~K}_{25} \mathrm{~S}_{18} \mathrm{Zn}_{2} \mathrm{~B}_{1.5}$ showed better performance on crop growth and yield of lentil and mustard as mixed cropping system in char land of Pabna. The maximum economic return in terms of gross return and gross margin was also recorded in the same fertilizer package.

\section{References}

Ahlawat, I.P.S. and R.P. Sharma. 1993. Agronomic Terminology, Indian Society of Agronomy, New Delhi, India, $3^{\text {rd }}$ edition.

BARI (Bangladesh Agricultural Research Institute). 1988 Annual Report for 1988, Joydebpur, Gazipur-1701, Bangladesh. pp.215-218.

Bhowal, S.K., M.M.U. Chowdhury, M.S. Bhuiyan, A.H.M.A. Faisal, I.S.M. Farhad and S.K. Bhowmik. 2014. Yield and Yield Attributes of Lentil (Lens esculenta) as ab Mixed Crop with Mustard (Brassica campestris). Sci. Agri. 8(2): 76-79.

Bhuiyan, M.A.H., D. Khanam, N.E. Ali, M.K. Zaman and M.S. Islam. 2008. Response of lentil to bio fertilizer and chemical fertilizers in the farmer's field. Annual Research Report, 2007-2008, Soil Science Division, BARI, Gazipur.pp.36-39.

Kazi, B. R. 2002. Effect of irrigation frequencies on growth and yield of soybean. 2(6): 661-662.

Kumar, S. and M.Singh. 2009. 25 Years of Pulses Research at IIPR, 19842009. Indian Institute of Pulses Research, Kanpur 208024, India.pp.6265.

Mohamed, S. A. 1984. Effect of irrigation water and fertilization on yield and water use efficiency of corn plants in Fayoum Governorate. Moshtohor, Egypt Annual Agril. Sci. 20(2): 221-235.

Mondal, R.H., B. Anwar, M. Rafiuddin and M.A. Hossain. 2010. Integrated nutrient management for sustaining soil fertility and yield of LentilMungbean-T. Aman cropping pattern. Annual Research Report, 20092010, Pulses Research Centre, Gazipur.pp. 82-86.

Perrin, R. K., Winkelmen, D.L., Moscardi, E.R. and Anderson, J.R. 1979. Economic Training Manual. Information Bulletin No. 27. CIMMYT, Mexico. p.5

Roy, R.K. and K.S. Singh. 1986. Response of pop-corn (Zea mays) to plant population and nitrogen. Indian J. Agron. 31(1): 87-92.

Singh, S.K., S.C. Varma and R.P. Singh. 2004. Residual effect of organic and inorganic sources of nutrients in lowland rice on succeeding lentil. Indian J. Agric. Res. 38(2): 121-125. 